\title{
Fertilizing behavior of extract of organomineral-activated biochar: low-dose foliar application for promoting lettuce growth
}

\author{
Abhay Kumar 1,2,3, Stephen Joseph ${ }^{4,5,6}$, Ellen R. Graber', Sara Taherymoosavi ${ }^{4}$, David R. G. Mitchell', \\ Paul Munroe ${ }^{4}$, Ludmila Tsechansky' ${ }^{1}$, Ove Lerdahl², Walter Aker ${ }^{2}$ and Mona Sæb $\varnothing^{3^{*}}$ (1)
}

\begin{abstract}
Background: Fostering plant growth and improving agricultural yields by adding "macro"-sized biochar to soil has been extensively explored. However, the impact and mechanism of action of aqueous extracts of biochar applied as foliar fertilizer on plant growth and physiology is poorly understood, and was the objective of this study. Extracts were produced from biochars derived from pine wood:clay:sand (PCS-BC; 70:15:15) and wheat straw:bird manure (WB-BC; 50:50) and tested at two dilutions each. The plant influence of the biochar extracts and dilutions were compared with chemical fertilizer made up to the same minor trace element compositions as the applied extracts and a control treatment consisting of only deionized water.
\end{abstract}

Results: The WB-BC extract was more alkaline than the PCS-BC extract and exhibited higher electrical conductivity values. Similar to the biochars from which they were derived, the WB-BC extract had higher concentrations of dissolved mineral elements and organic matter than the PCS-BC extract. Despite major differences in chemical composition between the PCS-BC and WB-BC extracts, there was virtually no difference in plant performance between them at any chosen dilution. Foliar application of PCS25, WB50, and WB100 led to a significant increase in the plant fresh biomass in comparison to their corresponding chemical fertilizer and to deionized water. Plant growth parameters including number of leaves and chlorophyll contents in plants treated with biochar extract foliar sprays were significantly higher than in all the other treatments. Electron microscopy and spectroscopy studies showed the deposition of macro- and nanoscale organomineral particles and agglomerates on leaf surfaces of the examined PCS25-treated plant. Detailed study suggests that carbon nanomaterials and $\mathrm{TiO}_{2}$ or $\mathrm{Si}$-rich nanoscale organomineral complexes or aluminosilicate compounds from biochar extract were main contributors to increased plant growth and improved plant performance.

Conclusion: These results suggest that biochar extracts have the potential to be used as nanofertilizer foliar sprays for enhancing plant growth and yield.

Keywords: Biochar aqueous-extract, Foliar spray, Lettuce, Nanofertilizers, Organomineral complexes, Plant growth

\footnotetext{
${ }^{*}$ Correspondence: mona.sabo@usn.no

${ }^{3}$ Department of Natural Sciences and Environmental Health, University of South-Eastern Norway, Gullbringvegen 36, 3800 Bø i Telemark, Norway Full list of author information is available at the end of the article
}

\begin{abstract}
Introduction
The demand for food for a growing world population is increasing rapidly [1]. In addition, industrialization and urbanization are causing contamination or reducing the availability of agricultural land suitable for crop production $[2,3]$. Extensive use of chemical fertilizers (CF) to maximize crop output is a key component of modern
\end{abstract}


intensive agrosystem, and one which increases every year [4]. However, CF application is often wasteful and inefficient as only one-third of the applied fertilizer is actually utilized by crops [5] and this has resulted in chronic chemical saturation [6]. The leaching of around twothirds of the applied fertilizers imposes an economic burden on agricultural producers and leads to environmental problems [7]. Therefore, for sustained crop productivity and food security, the current fertigation management strategy urgently needs to be improved.

An assortment of conventional soil husbandry strategies is available for enhancing soil fertility and crop productivity $[8,9]$. Out of many, biochar application to soil has potential to be a viable resource compared to access to modern technology for agricultural intensification [10, 11]. Biochar, a versatile carbonaceous material produced when biomass is pyrolyzed under controlled oxygen $(\mathrm{O})$ conditions [12], has been demonstrated to impact agricultural productivity in several ways: increasing intrinsic soil fertility [10]; enhancing soil biological activity [13]; improving soil physicochemical properties such as $\mathrm{pH}$, cation exchange capacity, water retention capacity, and enriching soil with mineral elements [14, 15]; reducing fertilizer requirement [16]; and increasing plant growth, health and productivity $[17,18]$. Yet, biochar properties vary as a function of a range factors like feedstock type, pyrolysis temperature and heating rate, and such differences in biochar physicochemical properties can result in differences in crop responses [12, 19]. Biochars with specific characteristics can be produced by regulating the proportions of appropriate feedstocks at the pre-pyrolysis stage [20]. For example, mixing clay and sand [21] or clay and $\mathrm{FeSO}_{4}[22]$ at the pre-pyrolysis stage produced biochar with a highly functionalized surface.

As a multi-beneficial amendment, biochar can be employed to increase plant resistance and immunity against biotic factors, such as foliar fungal pathogens [23, 24] and soil-borne diseases [25], as well as to enhance plants' tolerance to abiotic stress factors like salinity, drought, and heavy metals [14, 17, 26]. However, several studies have indicated that to obtain an effective response, relatively large amounts of biochar need to be applied. The amount may range between 10-50 t $\mathrm{ha}^{-1}$ depending on the soil and biochar characteristics [27-29]. This high application rate is costly and restricts its wider application [28]. Other factors such as use of feedstock(s) that are not suitable for producing biochar to soil applications, or recommendations for excessive application rates, limit its positive effects and can even be harmful [30]. Some studies have suggested that the use of biochar as a component of solid biochar-based fertilizer at a lower application rate [31] can enhance plant growth and production, reduce greenhouse gas emissions [32] and increase farmer income [33]. In a recent study, Lustosa Filho et al. [16] reported that the use of a biocharbased fertilizer significantly increased nutrient uptake efficiency and biomass production in Urochloa brizantha grass.

An alternative means of reducing biochar application rates may be by applying aqueous extracts of biochar as a spray, much as foliar sprays of chemical fertilizers are used for boosting crop yields [34]. Preliminary reports suggested that water extracts of biochars produced from various feedstocks (orange peel, residual wood, and water treatment sludge) had positive impacts on Lactuca sativa (lettuce) seed germination and seedling growth [35]. Lou et al. [36] reported that aqueous extracts of wheat and maize straw biochar applied on Brassica rapa plants promoted plant growth and induced higher levels of $C$ and total soluble proteins. In two different pot trials, foliar sprays made from water extracts of wheat straw biochar pyrolyzed at $350{ }^{\circ} \mathrm{C}$, applied together with nitrogen $(\mathrm{N})$, phosphorous $(\mathrm{P})$, and potassium $(\mathrm{K})$ compounds to Chinese cabbage, significantly increased plant yield [37]. Improved growth was attributed to increased gene expression of nitrate reductase and glutamine synthetase enzyme activities and reduced cadmium and lead concentrations when compared with control plants [38]. In contrast, an extract made from biochar prepared from wheat straw at $550{ }^{\circ} \mathrm{C}$ did not show any impact on plant growth and yield relative to controls [37, 38]. Thus, fundamental questions about which specific factors in biochar extracts play a significant role in plant growth promotion, and via what mechanisms still remain. The express purpose of the current study is to elucidate some of these factors.

Specifically, the present study tested two hypotheses: (i) impact of minor and trace mineral elements per se that are leached from the biochars during preparation of the aqueous extracts are not responsible for plant growth promotion. This was tested by comparing plant growth in treatments with extracts to plant growth in treatments with chemical fertilizers made up to the same minor and trace element compositions; and (ii) biochar-derived solubilized organic carbon (OC) in the extracts is responsible for plant growth promotion. This was tested by comparing efficacy of extracts with and without dissolved organic carbon (DOC). Lettuce was chosen as the model crop system.

\section{Materials and methods}

\section{Biochar production and characterization}

Two types of biochars were produced from various feedstocks: (i) pine wood:clay:sand (PCS-BC; 70:15:15 (w/w)) and (ii) wheat straw:bird (chicken) manure (WB-BC; $50: 50(w / w))$ pellets. Moisture content of the wood chips 
used in the PCS-BC production was $15-17 \%$ and their size was $10-15 \mathrm{~mm}$; dust and larger pieces were removed prior to pyrolysis. PCS-BC and WB-BC were produced at approximately $600-650{ }^{\circ} \mathrm{C}$ in a rotary kiln. The pressure in the unit was atmospheric pressure and the residence time for pyrolysis was $6 \mathrm{~min}$ at the highest temperature. Marine sedimentary clay and sand (moisture content 4-10\%) from Romania was used to coat the surface of the biochar with mineral nutrients and trace elements. The chemical analysis of clay and sand was conducted using an Elementar vario MACRO cube combustion analyzer. The samples were combusted at $1150{ }^{\circ} \mathrm{C}$. Major elements were measured after ashing using fluorescence (XRF) spectroscopy (Panalytical Axios X-ray). Chemical characteristics of the clay and sand used in the production of PCS-BC are given in Additional file 1: Table S1. Bird manure is an interesting waste stream due to its high concentration of nutrients, but its corrosive nature requires treatment before recycling. Pyrolysis is a suitable thermal treatment method for manure, and has been shown to yield high nutrient availability. Wheat straw has a relatively high amount of $\mathrm{K}$ and $\mathrm{P}$ [39], therefore, the idea of combining wheat straw with manure was based on the hypothesis that mixing these feedstocks may increase the available $\mathrm{K}$ and $\mathrm{P}$ in the final biochar product and make it more attractive for supplying plant $\mathrm{K}$ and $\mathrm{P}$ demand.

Surface area and porosity of biochar samples were determined using an automatic three station, surface area and porosity analyzer (TriStar II Plus 2.02). This instrument employs $\mathrm{CO}_{2}$ adsorption isotherm method as described by Dubinin-Radushkevich to determine the surface area of carbonaceous materials. A Malvern zetasizer Nano ZS was used to measure particle size and particle stability and charge structure. Finely ground biochar $(0.5 \mathrm{~g})$ was added to $50 \mathrm{ml}$ distilled water and sonicated for $30 \mathrm{~min}$. The suspension was then filtered using 0.45$\mu \mathrm{m}$ filters [40]. The zeta potential of the filtered biochar colloidal suspension was determined without $\mathrm{pH}$ adjustment. Biochar microstructure and chemical composition were investigated by a scanning electron microscope (NanoSEM 230, FEI, The Netherlands) configured with energy dispersive X-ray spectroscopy (EDS). Biochar specimens were coated with chromium $(\mathrm{Cr})$ to improve conductivity. EDS spectra were analyzed using proprietary software "Quantax", Esprit 1.9. Scanning transmission electron microscopy (STEM; JEOL ARM200F, JEOL Japan) coupled with an electron energy loss spectrometer (EELS) and an EDS detector was also performed to provide further morphologic and compositional information on the samples. Surface functionalities of finely ground biochar particles were identified using mono-chromated Al K alpha X-ray photoelectron spectroscopy (XPS; ESCALAB250Xi; Thermo Scientific, Waltham, USA) following the method described by Taherymoosavi et al. [41].

\section{Biochar extraction method and chemical characterization}

Ten $\mathrm{g}$ of biochar powder (particle size $<2.0 \mathrm{~mm}$ ) was added to $200 \mathrm{ml}$ of milliQ water, and the mixtures were boiled for $3 \mathrm{~h}$, brought back up to initial volume by adding milliQ water as some of water was evaporated, and then shaken on a rotary shaker at $180 \mathrm{rpm}$ at $25 \pm 2{ }^{\circ} \mathrm{C}$ for $20 \mathrm{~h}$. The mixtures were centrifuged at $5000 \mathrm{~g}$ for $10 \mathrm{~min}$ at $25{ }^{\circ} \mathrm{C}$, the supernatants were collected, filtered $(0.45 \mu \mathrm{m}$ PVDF filter), and analyzed for $\mathrm{pH}$, electrical conductivity (EC). Inorganic carbon and nitrogen contents were determined using a Total Organic Carbon Analyzer (Shimadzu, Japan). The concentration of dissolved major and trace elements in the solutions were measured using an inductively coupled plasma mass spectrometry (NexION Multi-Quadrupole ICP-MS, Perkin Elmer Inc., USA). A subsample was used for subsequent analysis of zinc $(\mathrm{Zn})$ and iron $(\mathrm{Fe})$, copper $(\mathrm{Cu})$, manganese $(\mathrm{Mn})$, magnesium $(\mathrm{Mg})$ and calcium $(\mathrm{Ca})$ by atomic adsorption spectroscopy (AAS, AAnalyst 400, Perkin Elmer, USA) and sodium ( $\mathrm{Na}$ ) and $\mathrm{K}$ by flame photometer (M410, Sherwood Scientific Ltd., UK) [42, 43]. Additionally, subsamples of biochar extracts were analyzed for DOC, including chromatographable dissolved organic carbon (CDOC) and hydrophobic organic carbon (HOC) fractions, using a DOC LABOR liquid chromatography-organic carbon detection (LC-OCD) [44].

\section{Pot experiment and treatment preparation}

The impact of foliar sprays (FS) prepared from the biochar extracts on plant growth was tested using lettuce (Lactuca sativa L.) plants in a pot experiment under natural light and greenhouse conditions. Soilless potting mixture (peat:tuff 7:3, v:v, Shacham Givat Ada, Israel) was mixed with $\mathrm{N}: \mathrm{P}_{2} \mathrm{O}_{5}: \mathrm{K}_{2} \mathrm{O}\left(0.2: 0.15: 0.2 \mathrm{~g} \mathrm{~kg}^{-1}\right.$ ) (supplied as ammonium nitrate, potassium phosphate, and potassium chloride, respectively) [36]. Pots $(1 \mathrm{~L})$ were filled with $600 \mathrm{~g}$ each soilless media premixed with NPK and wetted with deionized water to $60 \%$ pot holding capacity. Twelve-day-old lettuce seedlings, germinated separately, were transferred to the pots with one seedling per pot. Pots were irrigated with tap water daily 2 times for 2 min via 1 drip using an automatic drip irrigation system (Uniram1.5 L h ${ }^{-1}$, AS-17012, Netafim, Israel) lateral positioned at the center. Treatments were applied as FS to fully moisten the plant leaves (avoiding runoff) every 4 days for a total of 8 sprays until harvest at 32 days; the last treatment application was 4 days before harvesting.

Based on the $\mathrm{OC}$ and mineral concentrations, and prior studies [36-38], PCS-BC and WB-BC extracts were 
diluted at different ratios with deionized water $(\mathrm{v} / \mathrm{v})$ and used for FS application: PCS-BC extract was diluted 1:25 (PCS25) and 1:50 (PCS50), while WB-BC extract was diluted 1:50 (WB50) and 1:100 (WB100). For a comparative analysis, chemical fertilizer (CF) foliar spray solutions were prepared with the goal to replicate the minor and trace element compositions (Additional file 1: Table S2) of the PCS-BC and WB-BC extracts (Table 1). Major nutrients, N, P and $\mathrm{K}$ were not included in the $\mathrm{CF}$ preparations, as these major nutrients were supplied to all the treatments equally in the soil, as described above. CF solutions were diluted similarly to the biochar extract solutions to create working CF treatments. CF-PCS25, CF-PCS50, CF-WB50, and CF-WB100 are the chemical foliar spray equivalents of the PCS25, PCS50, WB50, and WB100 treatments, respectively. A ninth treatment consisted of deionized water (DW) as the foliar spray. Each of the nine treatments contained four biological replicates arranged randomly in four blocks.

\section{Plant analysis}

Plants were observed daily for the 32-day growing period. The target leaf for analysis was a fully developed mature leaf from heart of the plants. Photosystem II (PSII) efficiency of the target leaf was measured at 32 days following Sengupta et al. [45]. At the end of the experiment lettuce plants were harvested and the growth parameters including the number of leaves and fresh weight and dry weight of above ground biomass was calculated. Fresh leaf $(0.1 \mathrm{~g})$ from each treatment was chopped and kept in a micro centrifuge tube with $1.0 \mathrm{ml}$ of $80 \%$ acetone in distilled water $(\mathrm{v} / \mathrm{v})$ at $4{ }^{\circ} \mathrm{C}$ overnight. Photosynthetic pigments chlorophyll (Chl) $a, b$, total Chl and carotenoids in the extract were determined following Lichtenthaler [46] and expressed in $\mathrm{mg} \mathrm{g}^{-1} \mathrm{fw}$. Anthocyanins in fresh leaves were measured according to Kumar et al. [47] and expressed as $A_{535} g^{-1}$ fw.

Sampled leaves were washed, dried completely at 60 ${ }^{\circ} \mathrm{C}$, and ground into fine powder. Subsamples $(0.5 \mathrm{~g})$ were digested [48] with $10 \mathrm{ml} \mathrm{HNO}_{3}$ for subsequent analysis of $\mathrm{Zn}, \mathrm{Cu}, \mathrm{Fe}, \mathrm{Mn}, \mathrm{Ca}$ and $\mathrm{Mg}$ by $\mathrm{AAS}$, and $\mathrm{Na}$ and $\mathrm{K}$ by flame photometry.

\section{Microscopic and spectroscopy analysis of plant tissue}

Surface structures and elemental composition of the airdried leaf samples only from DW, PCS25, and CF-PCS25 plants were examined using a Phenom ProX Desktop SEM (ThermoFisher Scientific, Eindhoven, Netherlands) integrated with an EDS analyzer and elemental identification software for elemental mapping [14]. Plant-biochar

Table 1 Chemical characterization of hot water extract of biochar produced from two different feedstocks combinations: pine wood: clay: sand (PCS-BC; 70:15:15) and wheat straw:bird manure (WB-BC; 50:50)

\begin{tabular}{|c|c|c|c|c|}
\hline Chemical properties & PCS-BC extract & WB-BC extract & CF-PCS & CF-WB \\
\hline $\mathrm{pH}$ & $8.9 \pm 0.15$ & $10.3 \pm 0.05$ & 8.9 & 10.3 \\
\hline Electrical conductivity $\left(\mathrm{mS} \mathrm{cm}^{2}\right)$ & $0.06 \pm 0.005$ & $2.07 \pm 0.24$ & - & - \\
\hline $\mathrm{Zn}\left(\mathrm{mg} \mathrm{l}^{-1}\right)$ & $0.12 \pm 0.06$ & $0.25 \pm 0.11$ & 0.12 & 0.25 \\
\hline $\mathrm{Fe}\left(\mathrm{mg} \mathrm{l}^{-1}\right)$ & $1.31 \pm 0.27$ & $1.96 \pm 0.25$ & 1.31 & 1.96 \\
\hline $\mathrm{Cu}\left(\mathrm{mg} \mathrm{l}^{-1}\right)$ & $0.13 \pm 0.007$ & $0.15 \pm 0.01$ & 0.13 & 0.15 \\
\hline $\mathrm{Ca}\left(\mathrm{mg} \mathrm{l}^{-1}\right)$ & $2.8 \pm 0.11$ & $1.8 \pm 0.04$ & 2.80 & 1.8 \\
\hline $\operatorname{Mg}\left(\mathrm{mg} \mathrm{l}^{-1}\right)$ & $2.11 \pm 0.44$ & $1.73 \pm 0.49$ & 2.11 & 1.73 \\
\hline $\mathrm{Na}\left(\mathrm{mg} \mathrm{l}^{-1}\right)$ & $8 \pm 0$ & $347 \pm 10.7$ & 8.0 & 347 \\
\hline $\mathrm{Cl}\left(\mathrm{mg} \mathrm{l}^{-1}\right)$ & $15 \pm 2.8$ & $132 \pm 1.7$ & 1.5 & 1.1 \\
\hline$K\left(\mathrm{mg} \mathrm{l}^{-1}\right)$ & $13.3 \pm 1.3$ & $522 \pm 19.2$ & - & - \\
\hline$P\left(\mathrm{mg} \mathrm{l}^{-1}\right)$ & $0.58 \pm 0.09$ & $12.4 \pm 0.66$ & - & - \\
\hline Total N (mg l-1) & $0.62 \pm 0.12$ & $1.1 \pm 0.03$ & - & - \\
\hline Inorganic C $\left(\mathrm{mg} \mathrm{l}^{-1}\right)$ & $9.72 \pm 0.1$ & $65 \pm 2.3$ & - & - \\
\hline Dissolved organic $C\left(\mathrm{mg} \mathrm{l}^{-1}\right)$ & 62.5 & 675 & - & - \\
\hline Hydrophobic organic carbon (mg l-1) & 37.5 & 225 & - & - \\
\hline Chromatographable organic C $\left(\mathrm{mg} \mathrm{l}^{-1}\right)$ & 25 & 450 & - & - \\
\hline Bio-polymers (mg l-1) & 1.25 & 25 & - & - \\
\hline Humics $\left(\mathrm{mg} \mathrm{l}^{-1}\right)$ & 3.75 & 200 & - & - \\
\hline Building blocks (mg |-1) & 2.5 & 175 & - & - \\
\hline Low molecular weight neutrals (mg I ${ }^{-1}$ ) & 11.25 & 50 & - & - \\
\hline
\end{tabular}

Values for PCS-BC and WB-BC extract represent mean \pm SE of three replicates. Minor and trace element composition of PCS chemical fertilizer (CF-PCS) and WB chemical fertilizer (CF-WB) prepared to correspond PCS-BC extract and WB-BC extract, respectively 
extract interactions were examined in finely ground airdried leaf for DW and PCS25 treatments using STEM, EDS, and EELS $[49,50]$.

\section{Statistical analysis}

All data are shown as mean \pm standard error $(n=4)$. Differences between the treatments, comparing the effects of solution, dilution, and their interaction, were examined using a two-way analysis of variance (ANOVA) analysis (SIGMASTAT 12.0 Systat Software Inc., USA). Differences at level $(\alpha)$ of 0.05 were considered significant between treatments and are represented by different lowercase letters.

\section{Results}

\section{Biochar characteristics}

We engineered biochar production parameters to obtain biochars with the desired physicochemical properties (high specific surface area (SSA), mineral (ash) content, and alkaline $\mathrm{pH}$ ). Parameters included a relatively high pyrolysis temperature $\left(600-650{ }^{\circ} \mathrm{C}\right)$ that would result in encapsulation of woodchips with sand and clay for PCS$\mathrm{BC}$, and use of two different feedstocks (wheat straw and bird (chicken) manure) mixture for WB-BC production. The high pyrolysis temperature resulted in biochars having the desired properties (Additional file 1: Table S3).
As befitting the different starting feedstocks for the two biochar types, the physicochemical properties of PCS-BC and $\mathrm{WB}-\mathrm{BC}$ were different from each other (Additional file 1: Table S3). In particular, WB-BC produced from crop waste and manure-based biomass showed a higher surface area, micro-pore volume, aromaticity (specific adsorption coefficient/OC), and zeta potential in comparison to PCS-BC. Furthermore, WB-BC contained a much higher level of total dissolved $C$ (both inorganic and organic), DOC and total dissolved N. On the other hand, mineral encapsulation through mixing wood biomass with clay and sand enhanced the presence of mineral-rich macro- and nanoparticles on biochar surfaces as evident in the analysis of dissolved mineral trace elements (Additional file 1: Table S3). PCS-BC was rich in dissolved $\mathrm{Ca}, \mathrm{Mg}, \mathrm{Fe}, \mathrm{Mn}$, aluminum ( $\mathrm{Al})$, and molybdenum (Mo), while WB-BC contained a higher concentration of NPK and other dissolved elements including $\mathrm{Na}$, sulfur $(\mathrm{S})$, silicon $(\mathrm{Si}), \mathrm{Cu}$, and titanium (Ti). SEM and EDS analysis of a PCS-BC particle indicated the presence of aluminosilicate and complexes of $\mathrm{Ca}, \mathrm{K}$, and $\mathrm{Mg}$ on its surface (Fig. 1a). Other analyzed particles also indicated the presence of similar kind of minerals inside the pores of the biochar (red box) and on the matrix (red circle) (Additional file 1: Fig S1A). STEM analysis confirmed the SEM observations and provided information about the

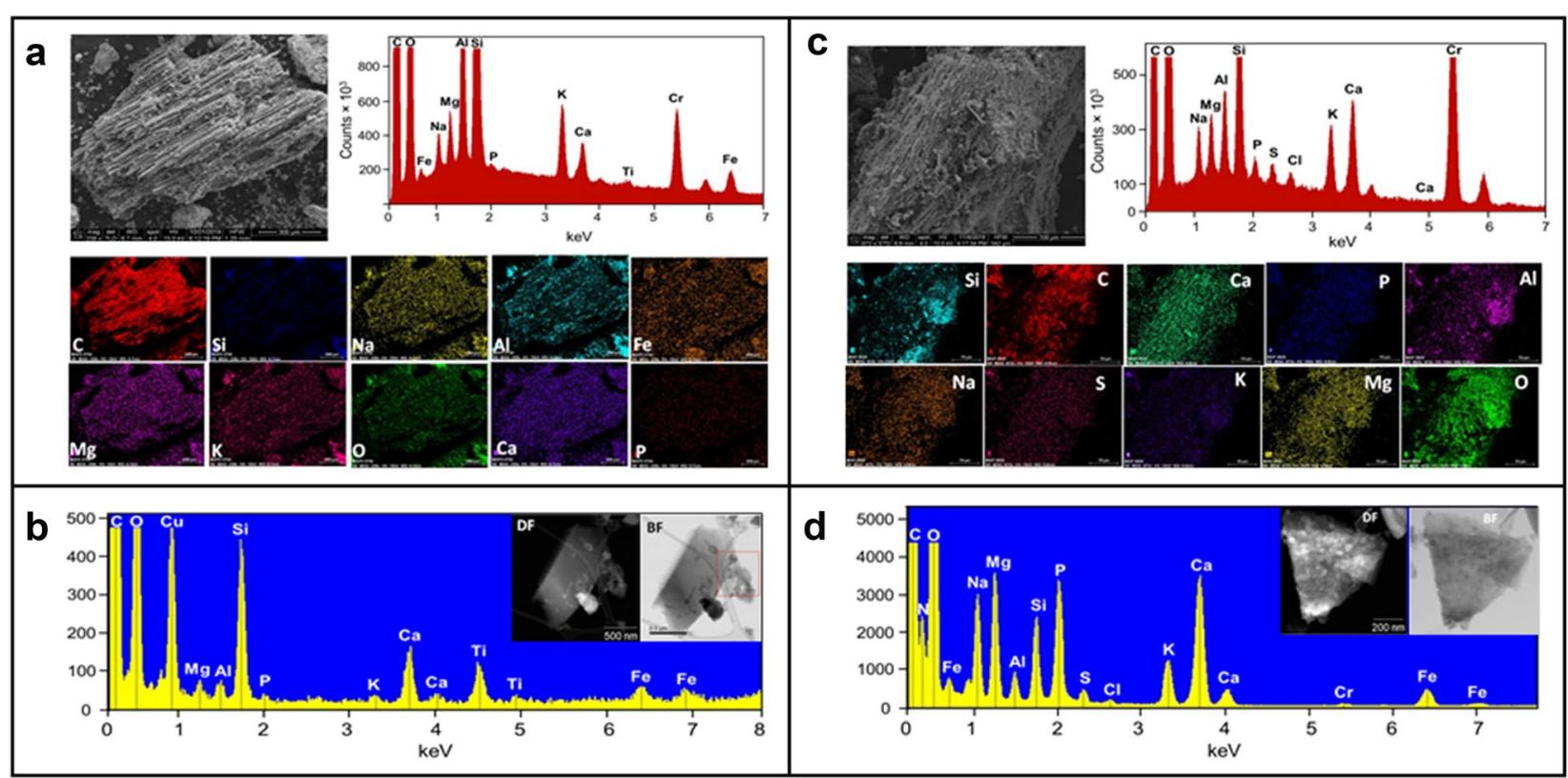

Fig. 1 Microscopy and spectroscopic examination of pine wood:clay:sand (PCS-BC; 70:15:15) and wheat straw:bird manure (WB-BC; 50:50) biochar. a Secondary electron image of a PCS-BC particle with an energy dispersive X-ray spectroscopy (EDS) spectrum and X-ray elemental map of the total area; $\mathbf{b}$ scanning transmission electron microscopy (STEM) dark field (DF) and bright field (BF) images along with an EDS spectrum of the PCS-BC particle; c secondary electron image of a WB-BC particle with an EDS spectrum and X-ray elemental map of the total area; and $\mathbf{d}$ STEM-DF and BF images along with an EDS spectrum of the WB-BC particle 
spatial resolution of identified phases (Fig. 1b). Two main phases were identified by EDS analysis (Additional file 1: Fig. S1B). One was the woody biochar and the other was a cluster of mineral compounds, rich in $\mathrm{Ca}, \mathrm{Si}$, and $\mathrm{Ti}$. In contrast to the PCS-BC, the WB-BC has much more complex surface structures with higher levels of organic and inorganic mineral complexes (Fig. 1c). An EDS spectrum of the whole area showed a higher concentration of $\mathrm{C}, \mathrm{O}, \mathrm{Si}, \mathrm{Ca}, \mathrm{K}, \mathrm{Al}, \mathrm{Mg}$, and $\mathrm{Na}$ with a lower concentration of $\mathrm{P}, \mathrm{S}$, and chloride (Cl) (Fig. 1c). Higher magnification images and EDS spectra revealed $\mathrm{Ca} / \mathrm{P}$-rich nanoparticle, probably sourced from bird manure, mixed with $\mathrm{Si}, \mathrm{C}, \mathrm{Al}$, $\mathrm{Mg}$ and $\mathrm{Na}$, attached to the surface of wheat straw particle (yellow box); there was also a cluster of aluminosilicates, combined with $\mathrm{K}, \mathrm{Mg}, \mathrm{Na}$ and $\mathrm{P}$, found within the inner layer WB-BC (yellow circle) (Additional file 1: Fig. S1C). High-angle annular dark field (HAADF) imaging and EDS elemental mapping shows the different distinct metals and non-metals are located on the C-matrix (Fig. 1d). Phase analysis indicated that Phase ' 1 ' is a mixture of $\mathrm{Mg}$, $\mathrm{Na}, \mathrm{P}, \mathrm{Ca}, \mathrm{K}$ and $\mathrm{N}$; Phase '2' is $\mathrm{CaCO}_{3}$; phase ' 3 ' probably indicates that $\mathrm{Fe}$ was bonded with aluminosilicate (also supported by the EDS elemental maps) (Additional file 1: Fig. S1D). XPS data confirmed the presence of two active $\mathrm{N}$ functional groups only in WB-BC (Additional file 1: Table S4). Furthermore, the atomic\% of $C$ functional groups were higher in PCS-BC than WB-BC, while functional groups related with $\mathrm{O}$ and trace elements such as $\mathrm{Ca}, \mathrm{Mg}, \mathrm{Si}, \mathrm{K}, \mathrm{Cl}, \mathrm{Na}, \mathrm{Fe}$, and $\mathrm{Al}$ were greater in WB-BC than in PCS-BC (Additional file 1: Table S4).

\section{Biochar extract characteristics}

WB-BC extract was more alkaline than the PCS-BC extract ( $\mathrm{pH} 10.3$ versus 8.9 ) and exhibited higher EC values $\left(207\right.$ versus $\left.5.5 \mathrm{mS} \mathrm{m}^{-1}\right)$. Similar to the biochars from which they were derived, the WB-BC extract had higher concentrations of $\mathrm{C}, \mathrm{N}$, and dissolved mineral element (Table 1) than did the PCS-BC extract. In particular, the WB-BC extract contained higher concentrations of dissolved $\mathrm{Zn}, \mathrm{Fe}, \mathrm{Na}, \mathrm{K}, \mathrm{P}$, and $\mathrm{Cl}$, while PCS-BC extract was richer in $\mathrm{Ca}$ and $\mathrm{Mg}$. Furthermore, WB-BC had a higher concentration of organic matter (OM) than PCS-BC, and higher total dissolved $\mathrm{C}$, total dissolved inorganicC, DOC, and total dissolved N (Table 1). Hydrophilic or chromatographable fraction of DOC, including biopolymers, humic-like substances, building blocks (polyphenols and polyphenolic acids), and low molecular weight (LMW) neutrals are presented in Table 1. WB-BC showed a higher proportion of biopolymers (5.5\%), humic-like substances (55.5\%), and building blocks (39.0\%) than the PCS-BC extract, while PCS-BC contained a greater content of LMW neutrals (about 50.0\%) than the WB-BC. As detailed, extracts were diluted by 25 and 50-fold, and 50 and 100-fold (PCS-BC and WB-BC, respectively) before use as foliar sprays.

\section{Plant growth and development}

Overall, plant growth in the groups treated by biochar extract foliar sprays (PCS25, PCS50, WB50, and WB100) was significantly better than in all the other treatments. Despite the differences in chemical composition between the PCS-BC and WB-BC extracts (Table 1), there was virtually no difference in plant performance between them at any of the chosen dilution levels. In contrast, comparative analysis between each biochar foliar spray treatment and its corresponding CF treatment showed that biochar extracts had significant positive impacts on the plant fresh biomass (Additional file 1: Fig. 2a) and compared with the DW treatment. Similar to fresh biomass, foliar application of PCS25 and WB50 led to a significant increase in the total number of leaves per plant in comparison to their corresponding CF (Fig. 2b). Indeed, growth performance in the CF treatments was not better than in the DW treatment.

\section{Plant physiology and mineral elements}

FS application of biochar extracts increased the Chl $a$ (Fig. 2c), Chl $b$ (Fig. 2d) and total Chl (Fig. 2e) in lettuce when compared with their corresponding CF and DW treatments, except for WB50 versus CF-WB50 in chl $a$ and chl $b$. In case of carotenoids, PCS25 and WB100 had significantly higher contents in comparison to CFPCS25 and CF-WB100, respectively (Fig. 2f). Plants from PCS25 and WB50 treatments (Fig. 2g) had significantly increased anthocyanins as compared with other treatments. Photochemical efficiency was insensitive to the treatments (Fig. 2h), as were mineral element contents in the leaves (Additional file 1: Table S5).

\section{Scanning electron microscopy study of leaf surface}

Despite major differences in chemical composition between the PCS-BC and WB-BC extracts, there was

\footnotetext{
(See figure on next page.)

Fig. 2 Effect of foliar spray application of pine wood:clay:sand (PCS-BC; 70:15:15) and wheat straw:bird manure (WB-BC; 50:50) biochar extract, at different dilution rates, on the lettuce plant growth parameters. a Fresh biomass; $\mathbf{b}$ number of leaves; c chlorophyll (Chl) $a$; d Chl $b$; and e total Chl; $\mathbf{f}$ carotenoids and $\mathbf{g}$ anthocyanins; and $\mathbf{h}$ quantum yield of photosystem II ( $\left.\mathrm{F}_{\mathrm{v}} / \mathrm{F}_{\mathrm{m}}\right)$. Different levels of chemical fertilizer (CF) were included to correspond each biochar extract treatment. A treatment consisting of only deionized water (DW) foliar spray was also included for comparison. Columns (means $\pm \mathrm{SE} ; n=4$ ) labeled by different lowercase letters are significantly $(p<0.05)$ different with each other
} 


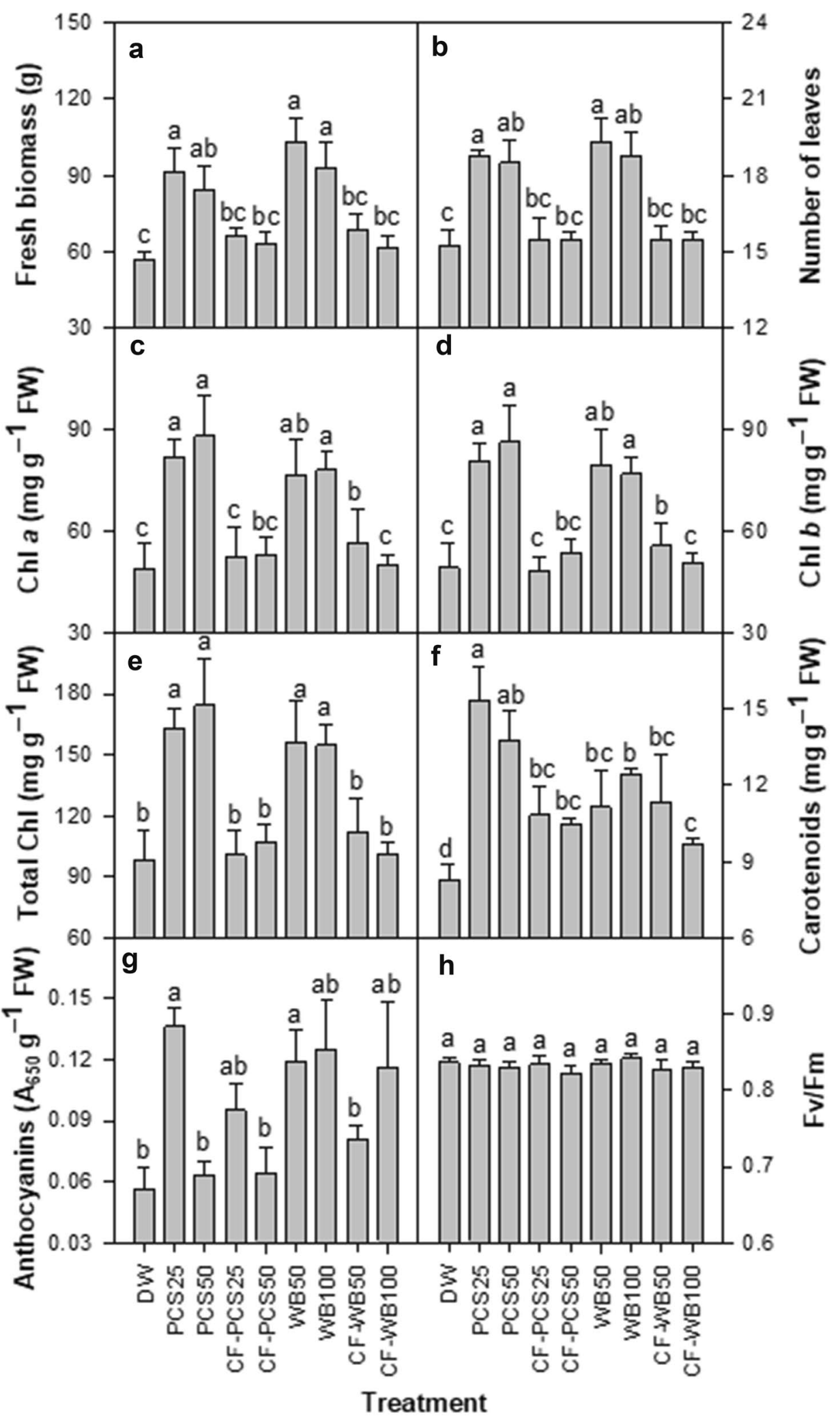


virtually no difference in plant performance between them at any chosen dilution. However, plants treated with PCS25 showed higher values for most of the plant parameters analyzed than PCS50, WB50, and WB100. Therefore, we selected the PCS25 for electron microscopy and spectroscopy analysis. An SEM image obtained from the DW leaf sample showed stomata (Fig. 3a) with no evidence of any associated mineral particles. The EDS spectrum of the entire area indicated the presence of $\mathrm{OM}(\mathrm{C}, \mathrm{N}, \mathrm{O})$ and mineral elements $\mathrm{S}, \mathrm{P}, \mathrm{K}, \mathrm{Cl}, \mathrm{Mg}$, and $\mathrm{Na}$ (Fig. 3b). In contrast, SEM and EDS analysis of a PCS25-treated leaf indicated that macro-organomineral particles and nanoscale agglomerates were deposited on leaf surfaces as well as inside the stomata (Fig. 3c). An EDS spectrum of the cropped area confirmed the deposition of $\mathrm{Na}, \mathrm{Mg}, \mathrm{Al}, \mathrm{Si}, \mathrm{S}, \mathrm{P}, \mathrm{Ca}, \mathrm{K}$, and Fe (Fig. 3d). A higher magnification image (Fig. 3e) of the nanoscale particles inside the stomatal opening and the EDS spectrum (Fig. 3f) confirmed that these clusters were Si-rich organomineral complexes or $\mathrm{Ca}, \mathrm{Fe}$, and $\mathrm{K}$ silicate compounds. Elemental map analysis of another area on the leaf surface showed the deposition of biochar-derived organic molecules associated with $\mathrm{N}, \mathrm{K}, \mathrm{P}, \mathrm{O}, \mathrm{Na}, \mathrm{Mg}$, $\mathrm{Si}, \mathrm{S}$, and $\mathrm{Ca}$ (Additional file 1: Fig. S2). Furthermore, despite the presence of several toxic heavy metals in both biochars, SEM-EDS analysis of PCS25-treated lettuce
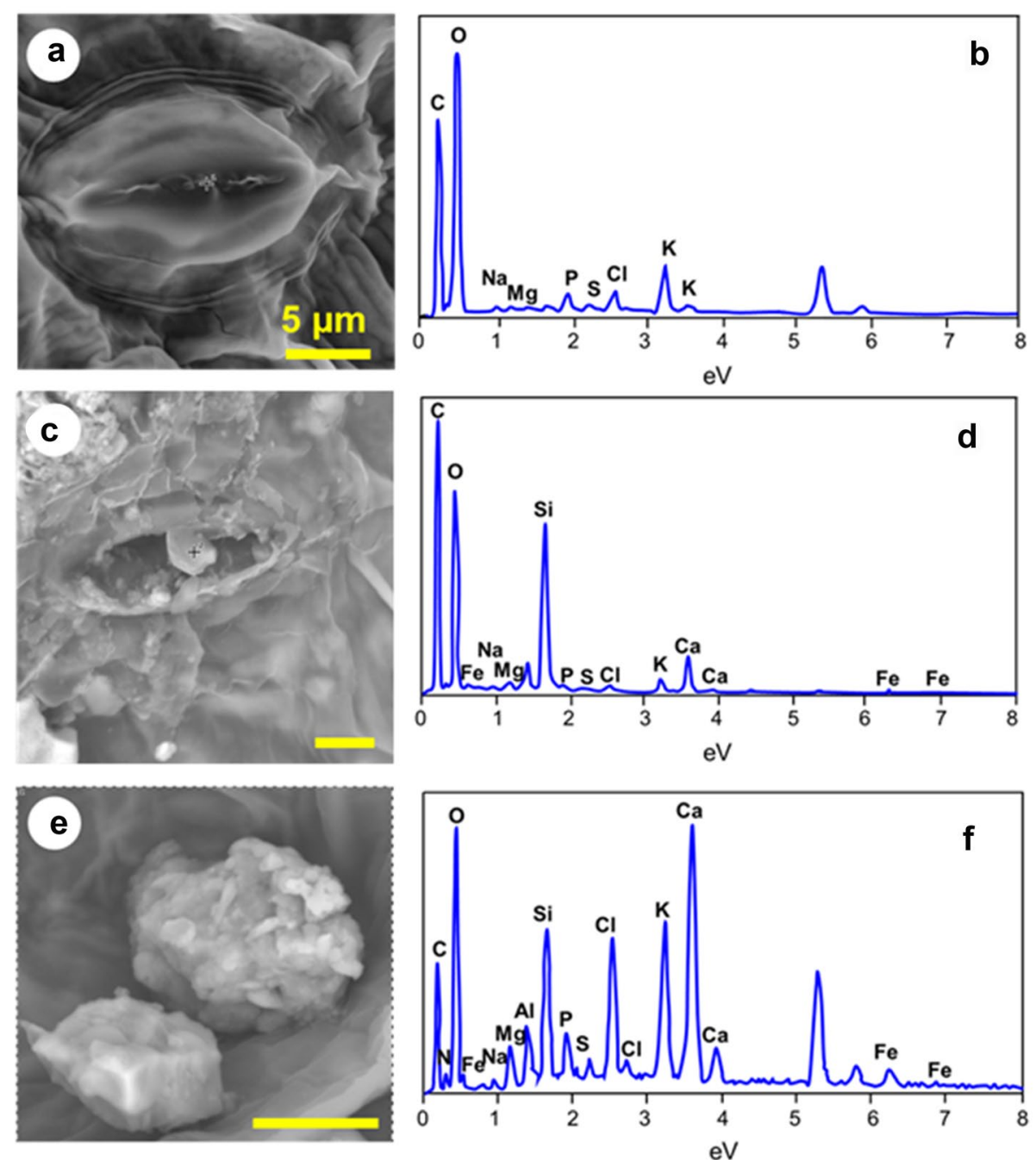

Fig. 3 Scanning electron microscopy (SEM) and energy dispersive X-ray spectroscopy (EDS) of DW (deionized water) and PCS25 (foliar spray of pinewood, clay, and sand biochar extract at 1:25 dilution) treated lettuce adaxial leaf surface. a Secondary electron image of control leaf showing stomata; $\mathbf{b}$ EDS spectrum of $\mathbf{a}$; $\mathbf{c}$ secondary electron image of PCS25-treated leaf showing stomata and presence of organomineral complexes; $\mathbf{d}$ EDS spectrum of $\mathbf{c}$; e high-resolution SEM image showing the organomineral complex formed or associated inside the stomata. $\mathbf{f}$ EDS spectrum of $\mathbf{e}$ showing the presence of high mineral complexes 
leaf did not show the deposition of any toxic heavy metals on the leaf surface.

\section{Scanning transmission electron microscopy and spectroscopy study of leaf powder}

STEM-EDS analysis of PCS25-treated leaf revealed the presence of a particle with a porous $\mathrm{C}$-matrix containing distinct nanoscale particles (Fig. 4a). The EDS spectrum (Fig. 4b) and elemental map (Fig. 4c) confirmed that these nanoscale particles contained oxidized compounds of $\mathrm{OM}$ associated with $\mathrm{N}, \mathrm{Al}, \mathrm{Si}, \mathrm{K}, \mathrm{Fe}, \mathrm{Ti}$, and $\mathrm{Mg}$ with trace amount of $\mathrm{P}, \mathrm{S}$, and $\mathrm{Ca}$. Phase analysis indicated that phase- 1 is mixture of aluminosilicate and $\mathrm{TiO}_{2}$ containing $\mathrm{N}, \mathrm{K}, \mathrm{Ca}$, and $\mathrm{Fe}$ (Additional file 1: Fig. S3A). Phase-2 is probably an aluminosilicate compound (Additional file 1: Fig. S3B) and phase-3 represents Fe-bound Si-rich compounds accompanied by $\mathrm{TiO}_{2}$ (Additional file 1: Fig. S3C).

STEM-EDS of another fragment from leaf powder shows a mineral-rich $(\mathrm{N}, \mathrm{Si}, \mathrm{Al}, \mathrm{K}, \mathrm{P}, \mathrm{S}, \mathrm{Mg}, \mathrm{Fe}$, and Ti) biochar particle (Fig. 5a and b). The HAADF image (Fig. 5d and Additional file 1: S4A) and EDS analysis (Fig. 5e and Additional file 1: Fig. S4B) of the cropped area in Fig. 5a shows that nanoscale-mineral aggregates embedded in the biochar along with high level of Si. K-edge EELS1 reveals that the $\mathrm{C}$ in the cropped area of Fig. 5a is functionally active with $\mathrm{N}$ and $\mathrm{O}$ containing groups with energies at $285 \mathrm{eV}$ (Fig. 5c) and $360 \mathrm{eV}$ (Fig. 5f) in the C-matrix and around the mineral phases on the redox active biochar surface. The HAADF image alone with the EDS spectrum shows porous C-matrix with sub nanometer clusters or individual atoms of $\mathrm{N}$, $\mathrm{Mg}, \mathrm{Al}, \mathrm{Si}, \mathrm{P}, \mathrm{K}$, and $\mathrm{Ca}$ (Additional file 1: Fig. S4C and D). Figure $5 \mathrm{~g}$ is a secondary electron image of a mineraldeposited biochar surface marked as EELS2 in Fig. 5a. The EDS spectrum (Fig. 5h) and associated Fe L-edge EELS spectrum at $728 \mathrm{eV}$ (Fig. 5i) are suggestive of super paramagnetic iron-oxide complex or maghemite or Ferich phases in nanoparticles less than $5 \mathrm{~nm}$ in diameter together with other mineral complexes on the biochar surface.

\section{Discussion}

Performance of plants treated with biochar extract foliar sprays was significantly better than that of plants treated with equivalent chemical foliar sprays providing the same

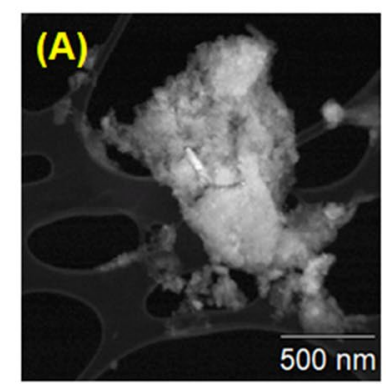

(C)

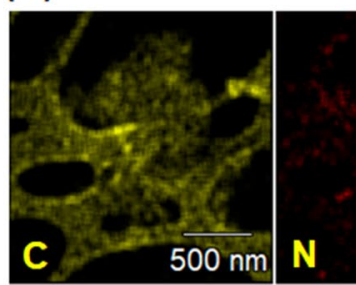

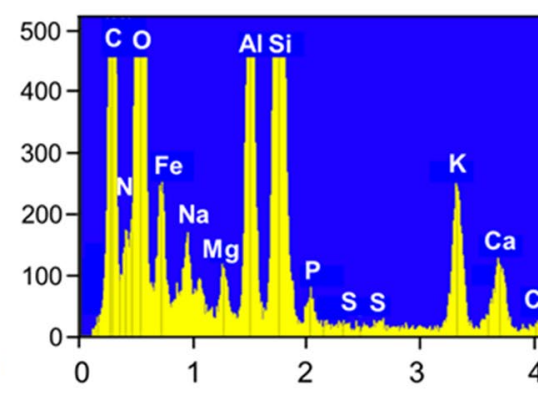

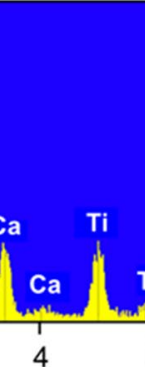

$\mathrm{keV}$

(B)

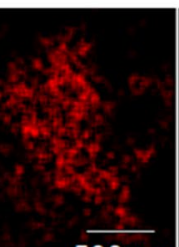

$500 \mathrm{~nm}$
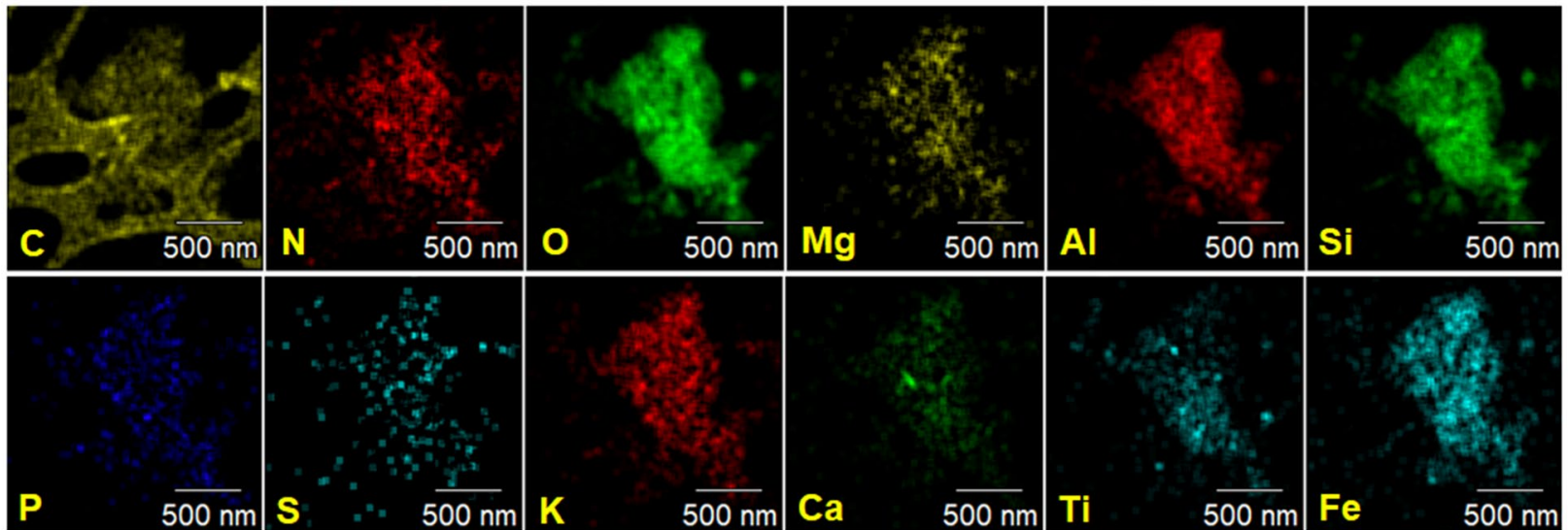

Fig. 4 Scanning transmission electron microscopy (STEM), energy dispersive X-ray spectroscopy (EDS) analysis of a PCS-BC (pine wood, clay, and sand biochar) particle from foliar application of PCS25 (PCS biochar extract at 1:25 dilution) treated plant leaf powder. a Secondary electron micrograph of an identified biochar particle showing nanoscale agglomerate in the C-matrix. $\mathbf{b}$ EDS spectrum of total identified area; and $\mathbf{c}$ elemental map of biochar particle indicating the presence of mineral elements on the surface of identified particle 


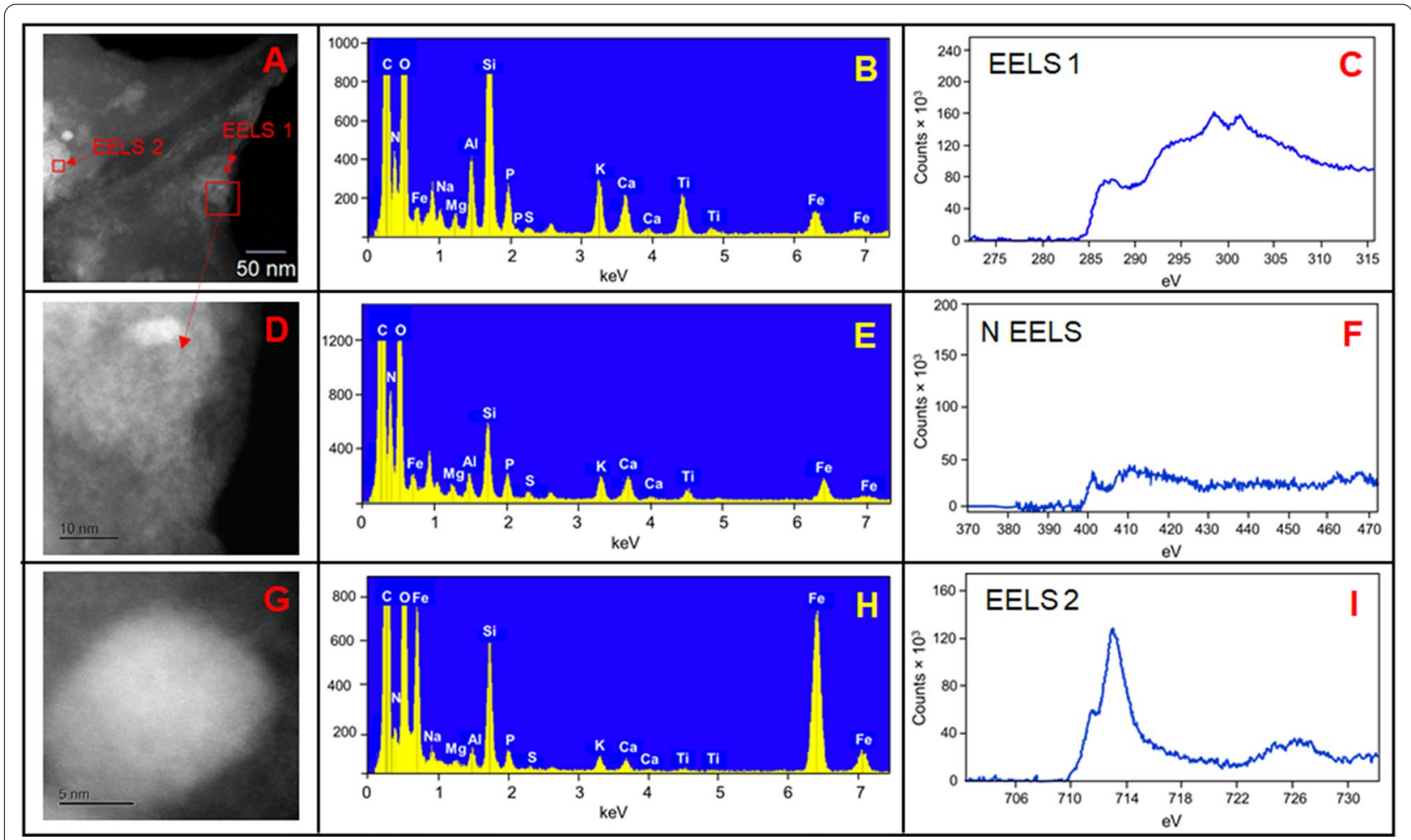

Fig. 5 Scanning transmission electron microscopy and electron energy loss spectroscopy (EELS) of leaf powder form foliar spray of PCS25 (pine wood, clay, and sand biochar extract at 1:25 dilution) treated lettuce plant. Micrographs were obtained from different ultra-thin sections of the same biochar particle from Fig. 4. a Transmission electron microscopy (TEM) high-angle annular dark field (HAADF) micrograph and EELS spectra of an ultra-thin section of the nanoscale agglomerate revealing its mineral compositions in their respective $\mathbf{b}$ EDS spectrum. $\mathbf{c}$ EELS spectrum of region 1 marked in a. d HAADF micrograph of cropped area in $\mathbf{a}$ and its representative e EDS spectrum. $\mathbf{f} \mathrm{N}$-EELS spectrum of the marked area in $\mathbf{a}$. $\mathbf{g} \mathrm{HAADF}$ image of EELS 2 marked in $\mathbf{a}$. $\mathbf{b}$ EDS spectrum of $\mathbf{g}$ and its EELS spectrum is presented in $\mathbf{i}$

content of minor and trace elements. Together with that, the two different biochar foliar sprays worked equally well, and equally at two different concentrations, despite the large differences between them in terms of the elements present and $\mathrm{OC}$ content. Thus, the first hypothesis of this study, that the minor and trace mineral elements per se that are leached from the biochars during preparation of the aqueous extracts are not responsible for plant growth promotion was found to be correct. This means there must be an alternative explanation for the clear positive impact of the biochar extract foliar sprays. Yet, the second hypothesis, that biochar-derived solubilized OC in the extracts is responsible for promoting plant growth, was found to be incorrect in our experimental conditions. The WB-BC extract has a substantially greater concentration of $\mathrm{OC}$ and of the different $\mathrm{OC}$ components than the PCS-BC extract, yet, it did not outperform the PCS-BC extract in terms of plant growth. However, it does not exclude the possibility that the biochar-derived solubilized OC may contain a same concentration range of specific organic molecule or a group of compounds or organo-mineral complexes, both in WB-BC and PCS-BC, acting as plant promoting agent in a similar capacity.

One obvious difference between the CF and biochar extract preparations is the presence of the major nutrients $\mathrm{K}$ and $\mathrm{P}$ in the biochar extracts (Table 1) and their absence in the CF preparations. However, a comparison between the two extracts shows that while dissolved $\mathrm{K}$ and $\mathrm{P}$ concentrations of the WB-BC extract are 40 and 20 times greater than of the PCS-BC extract, respectively, there is no difference between the extracts in their impact on plant performance. Moreover, the absolute concentrations of dissolved $\mathrm{K}$ and $\mathrm{P}$ in the foliar sprays made up from the extracts are very low in comparison to such nutrients supplied in conventional foliar sprays for supplemental fertilization [51]. Thus, this does not seem to be the reason for the efficacy of the biochar foliar sprays.

The only other major difference between the biocharderived foliar sprays and the chemical foliar sprays is the presence of complex mineral/organic nanoparticles in the biochar-derived sprays. In terms of this feature, extracts of both biochars were similar, despite the difference 
between them in overall chemical and structural properties. Both PCS-BC and WS-BC had an abundance of active functional groups on mineral and organic matter surfaces and in pore spaces that were lined or filled with organomineral coatings and nano/micro-agglomerates $[52,53]$. STEM/EDS characterization showed that these nanoscale $(<100 \mathrm{~nm})$ organomineral particles have unique structural and chemical properties. We suggest the biochar-derived nanoparticles, loaded with mineral elements and possessing high surface area and porosity, act as "nanofertilizers" on the leaf surfaces.

Nanofertilizers refer to nanoscale-dimension products that bring nutrients to crops either via minerals encapsulated inside nanomaterials or as particles. Nanofertilizers have shown the potential to increase crop productivity by enhancing seed germination and growth, plant development, photosynthetic functions, carbohydrate metabolisms, in addition to improving stress tolerance [54-56]. Additionally, nanofertilizers foliar applications on the leaves have been found to affect the biological function and microbial communities in soil [57]. A precise application rate of nanofertilizers can feed plants gradually in a controlled manner and promote plant growth rate [58] along with the benefits of increasing the fertilizer use efficiency via a slow release [59], minimizing nutrient leaching loss into the environment [60]. Among other benefits, nanofertilizers can be applied in a comparatively smaller amount to CF, ultimately increasing ease of application and with clear economic benefits [61]. The main focus of many studies was a comparison between foliar nanofertilizer application and a control water treatment. Only a few studies compared the effect of nanofertilizers with non-nanofertilizer or CF treatments. A study of Caborate nanoparticles containing foliar spray on lettuce and Cucurbita pepo revealed growth-inducing properties in comparison to the control (water only) plants and plants treated with only boron commercial fertilizer [62]. In a field experiment with tomato plants, foliar application of NPK nanofertilizers demonstrated that NPK nanofertilizers applied at $50 \%$ and $25 \%$ of the recommended level gave higher crop yield and yield parameters viz. economic yield, harvest index, starch rates, nutrient use efficiency, and production quality compared to NPK chemical fertilizer applied at recommended levels [63].

These previous studies found that foliar application of nanofertilizers increased nutrient concentrations in plant parts when compared to the plants treated with similar CF. In stark contrast, our experiment did not reveal any significant impacts on the mineral elements in lettuce leaves between the different treatments. Previously, it was postulated that increased plant growth was the function of cations, anions $[35,36]$ and nanofertilizers present in biochar extracts [64]. Relating to this hypothesis, our results are suggestive that nanoscale organomineral complexes like $\mathrm{TiO}_{2}, \mathrm{SiO}_{2}$, and $\mathrm{Fe}_{2} \mathrm{O}_{3}$ containing $\mathrm{N}, \mathrm{K}$, and $\mathrm{Ca}$ or aluminosilicate compounds in the biochar extracts were involved in the observed enhanced plant growth. Irrespective of their concentrations in biochar extracts, DOM, humic substances, and low molecular weight compounds can possibly participate in a variety of chemical and biological redox-mediated reactions through the solubilization of redox active molecules $[38,65]$. By this way, the biochar extract could affect the various key plant processes and ultimately increase the plant growth and development [65]. A study where the combined effect of different nanofertilizers mixture (Pharmks) and humic acid was tested on black cumin seedlings revealed much increased plant growth index in comparison to seedlings treated with either only Pharmks or humic acid alone [66]. The effect of the foliar application of various doses of $\mathrm{ZnO}$ nanoparticles alone, and in combination with soil-applied biochar have showed an improved plant growth response such as biomass, height, and number of leaves of maize seedlings in comparison to the nontreated control when grown in Cd contaminated soil [67]. However, the combination of the two, $\mathrm{ZnO}$ nanoparticles and biochar, showed much better response than application of $\mathrm{ZnO}$ nanoparticles alone [67].

To understand the fundamental and quantitative mechanisms of nanofertilizer-mediated plant growth, an in-depth analysis of the interactions between nanoparticles and plant leaves is crucial. Therefore, SEM-EDS analysis was conducted with the biochar extract-treated leaf, which confirmed the presence of OM and mineralassociated $\mathrm{C}$ nanoparticles on leaf surfaces and in stomatal openings. Interactions between nanoparticles with leaves revealed that the translocation of nanomaterials into leaf tissue or apoplast is through stomatal openings or nano-pores located on the leaf cuticle or surface [64, 68]. The apoplastic presence of mineral elements played an important role in the plant developmental processes [69]. This accords with the observed increase in lettuce biomass and increase in photosynthetic pigments under treatment with the nanoparticle-rich foliar extracts as compared with the chemical foliar sprays. It is suggestive that nanoscale organomineral complexes in the extracts interacted with leaf surfaces and were transported into plant tissues through stomata via gas uptake.

Biochar-derived $\mathrm{C}$ nanoparticles have likewise been seen to enhance plant performance in terms of leaf photosynthetic pigments $[70,71]$. These increased pigments concentrations can also be correlated with the increase in number of leaves, plant growth, and biomass. With their unique physicochemical properties, foliar sprays of minerals containing C-nanomaterial or biochar nanofertilizers can regulate the physiological and biochemical 
processes in plants [72]. Increases in these pigments are indicative of a direct interaction between nanoscale organomineral complexes with leaf cellular organelles. Possibly, mineral elements from these complexes could have directly enhanced the biosynthesis of Chl molecules or stabilization of pigment-protein complexes. Rossi et al. [73] reported that foliar application of $\mathrm{ZnO}$ nanofertilizer significantly improved the net photosynthetic rate, in addition to the growth and physiology of coffee plants when compared with plants treated with either DW or zinc sulphate.

Carotenoids and anthocyanins are widely available pigments in plants and are well known for their role in growth enhancement and in strengthening plant defense mechanisms as they act as non-enzymatic antioxidants to maintain cellular oxidative balance [74, 75]. Körösi et al. [76] reported that foliar application of $\mathrm{TiO}_{2}$ nanoparticles enhanced the antioxidative properties of a Vitis vinifera leaf via inducing the total phenolic content and biosynthesis of flavonoids and increased accumulation of mineral elements. Similarly, $\mathrm{SiO}_{2}$ nanoparticles, when sprayed on a pakchoi plant had a positive impact of inducing relative abundance of several metabolites, sugars and sugar alcohols, fatty acids, and small molecules organic acids in these plants [57]. Higher carotenoids and anthocyanins levels in biochar extract-treated plants leaves have suggested its increased production for healthy and better growth of lettuce $[10,77]$. It could be possible that $\mathrm{TiO}_{2}, \mathrm{SiO}_{2}$ and other mineral nanoparticles associated with the C-matrix, as observed in Fig. 4, enhanced the synthesis and accumulation of carotenoids and anthocyanins in the lettuce. Under our experimental conditions, the lettuce plants were healthy and unstressed, as evidenced by the optimal $\mathrm{F}_{\mathrm{v}} / \mathrm{F}_{\mathrm{m}}$ values [78].

\section{Conclusion}

A low-dose application of aqueous extract derived from PCS-BC and WB-BC improve lettuce plant growth and physiological attributes when grown in soilless media under natural conditions. The increased lettuce growth could be directly related with the increased photosynthetic pigment concentrations. Electron microscopy and spectroscopic studies are indeed suggestive that organomineral nanoparticle complexes and $C$ nanomaterials from the foliar-applied biochar extracts were the main contributors to this increased plant growth and performances. Such porous nanofertilizers can slowly release minerals over time, in accordance with plant needs, in contrast to what occurs with CF. The overall results suggest that biochar extracts have the potential to be highly effective foliar nanofertilizers for improving plant growth. In the future, testing a foliar spray rich in OC nanoparticles, but poor in mineral elements in comparison to those used in this study, will enhance our understanding of the potential role of $\mathrm{C}$ nanoparticles in promoting plant growth. Furthermore, future study should include a quantitative analysis of bioavailability of toxic heavy metals in the biochar extracts, by examining their uptake in plant leaves and related plant responses.

\begin{abstract}
Abbreviations
CF: Chemical fertilizer; DOC: Dissolved organic carbon; EDS: Energy dispersive X-ray spectroscopy; EELS: Electron energy loss spectrometer; FS: Foliar sprays; HAADF: High-angle annular dark field; OC: Organic carbon; OM: Organic matter; PCS-BC: Pinewood, clay, and sand biochar; SEM: Scanning electron microscope; STEM: Scanning transmission electron microscope; WB-BC: Wheat straw and bird manure biochar; XPS: X-ray photoelectron spectroscopy.
\end{abstract}

\section{Supplementary Information}

The online version contains supplementary material available at https://doi. org/10.1186/s40538-021-00222-x.

Additional file 1. Experimental details, Tables S1-S5 Figures S1-S4.

\section{Acknowledgements}

A.K. gratefully acknowledges The Volcani Center, Agriculture Research Organization, Israel, for a Postdoctoral fellowship, as well as a University of South Eastern Norway, Bø, Norway, Standard Bio, Norway, and University of South Wales, Australia for Postdoctoral Research Associate Fellowship to conduct this research.

\section{Authors' contributions}

All authors of this research paper have directly contributed in the conceptualization, execution, designing of the experiment, statistical analysis and manuscript preparation of the study. All authors read and approved the final manuscript.

\section{Funding}

This research did not receive any funding.

Availability of data and materials

All data generated during this study are included in this article.

\section{Declarations}

Ethics approval and consent to participate

Not applicable.

\section{Consent for publication}

Not applicable.

\section{Competing interests}

The authors declare that they have no competing interests.

\section{Author details}

${ }^{1}$ Department of Soil Chemistry, Plant Nutrition and Microbiology, Institute of Soil, Water and Environmental Sciences, Agricultural Research Organization, Volcani Center, 7505101 Rishon LeZion , Israel. ${ }^{2}$ Standard Bio, Televegen 2, 3802 Bø i Telemark, Norway. ${ }^{3}$ Department of Natural Sciences and Environmental Health, University of South-Eastern Norway, Gullbringvegen 36, 3800 Bø i Telemark, Norway. ${ }^{4}$ School of Materials Science and Engineering, University of NSW, Sydney, NSW 2052, Australia. ${ }^{5}$ Institute of Resource, Ecosystem and Environment of Agriculture, Nanjing Agricultural University, Nanjing 210095, Jiangsu, China. ${ }^{6}$ ISEM and School of Physics, University of Wollongong, Wollongong, NSW 2522, Australia. ${ }^{7}$ Electron Microscopy Centre, AllM Building, Innovation Campus, University of Wollongong, Squires Way, North Wollongong, NSW 2517, Australia. 
Received: 10 December 2020 Accepted: 18 March 2021

Published online: 12 May 2021

\section{References}

1. Carvalho FP. Pesticides, environment, and food safety. Food Energy Secur. 2017;6:48-60.

2. Liu Y, van Oort F, Geertman S, Lin Y. Institutional determinants of brownfield formation in Chinese cities and urban villages. Habitat Internat. 2014:44:72-8

3. Zwolak A, Sarzyńska M, Szpyrka E, Stawarczyk K. Sources of soil pollution by heavy metals and their accumulation in vegetables: a review. Water Air Soil Pollut. 2019;230:164

4. Otálora G, Piñero MC, López-Marín J, Varó P, del Amor FM. Effects of foliar nitrogen fertilization on the phenolic, mineral, and amino acid composition of escarole (Cichorium endivia L. var. latifolium). Scientia Horticult. 2018:239:87-92.

5. Withers PJA, Sylvester-Bradley R, Jones DL, Healey JR, Talboys PJ. Feed the crop not the soil: rethinking phosphorus management in the food chain. Environ Sci Technol. 2014;48:6523-30.

6. Kumar R, Kumar R, Prakash O. The impact of chemical fertilizers on our environment and ecosystem. Res Trends Environ Sci. 2019;35:69-86.

7. Fixen P, Brentrup F, Bruulsema T, Garcia F, Norton R, Zingore S. Nutrient/ fertilizer use efficiency: measurement, current situation and trends. Manag Water Fertil Sustain Agric Intensif. 2015;270:8-38.

8. Bindraban PS, Dimkpa C, Nagarajan L, Roy A, Rabbinge R. Revisiting fertilisers and fertilisation strategies for improved nutrient uptake by plants. Biol Fertil Soils. 2015;51:897-911.

9. Dimkpa CO, Fugice J, Singh U, Lewis TD. Development of fertilizers for enhanced nitrogen use efficiency - Trends and perspectives. Sci Total Environ. 2020;731:139113

10. Kumar A, Elad Y, Tsechansky L, Abrol V, Lew B, Offenbach R, Graber ER. Biochar potential in intensive cultivation of Capsicum annuum L. (sweet pepper): crop yield and plant protection. J Sci Food Agric. 2018;98:495-503.

11. Oni BA, Oziegbe O, Olawole OO. Significance of biochar application to the environment and economy. Ann Agric Sci. 2019;64:222-36.

12. Elkhalifa S, Al-Ansari T, Mackey HR, McKay G. Food waste to biochars through pyrolysis: a review. Resour Conserv Recycl. 2019;144:310-20.

13. Song D, Xi X, Zheng Q, Liang G, Zhou W, Wang X. Soil nutrient and microbial activity responses to two years after maize straw biochar application in a calcareous soil. Ecotoxicol Environ Saf. 2019;180:348-56.

14. Kumar A, Joseph S, Tsechansky L, Schreiter IJ, Schüth C, Taherysoosavi S, Mitchell DRG, Graber ER. Mechanistic evaluation of biochar potential for plant growth promotion and alleviation of chromium-induced phytotoxicity in Ficus elastica. Chemosphere. 2020;243:125332.

15. Joseph S, Pow D, Dawson K, Mitchell DRG, Rawal A, Hook J, Taherymoosavi S, Van Zwieten L, Rust J, Donne S, Munroe P, Pace B, Graber E, Thomas T, Nielsen S, Ye J, Lin Y, Pan G, Li L, Solaiman ZM. Feeding biochar to cows: an innovative solution for improving soil fertility and farm productivity. Pedosphere. 2015;25:666-79.

16. Lustosa Filho JF, Carneiro JS, Barbosa CF, de Lima KP, Leite AA, Melo LCA. Aging of biochar-based fertilizers in soil: effects on phosphorus pools and availability to Urochloa brizantha grass. Sci Total Environ. 2020;709:136028.

17. Abideen Z, Koyro H-W, Huchzermeyer B, Ansari R, Zulfiqar F, Gul B. Ameliorating effects of biochar on photosynthetic efficiency and antioxidant defence of Phragmites karka under drought stress. Plant Biol. 2020;22:259-66.

18. Jaiswal AK, Elad Y, Cytryn E, Graber ER, Frenkel O. Activating biochar by manipulating the bacterial and fungal microbiome through pre-conditioning. New Phytol. 2018;219(1):363-77.

19. Jaiswal AK, Elad Y, Graber ER, Frenkel O. Rhizoctonia solani suppression and plant growth promotion in cucumber as affected by biochar pyrolysis temperature, feedstock and concentration. Soil Biol Biochem. 2014;69:110-8.

20. Yang X, Ng W, Wong BSE, Baeg GH, Wang C-H, Ok YS. Characterization and ecotoxicological investigation of biochar produced via slow pyrolysis: effect of feedstock composition and pyrolysis conditions. J Hazard Mater. 2019;365:178-85.
21. Zhao Z, Zhou W. Insight into interaction between biochar and soil minerals in changing biochar properties and adsorption capacities for sulfamethoxazole. Environ Pollut. 2019:245:208-17.

22. Pace B, Munroe P, Marjo CE, Thomas P, Gong B, Shepherd J, Buss W, Joseph $\mathrm{S}$. The mechanisms and consequences of inorganic reactions during the production of ferrous sulphate enriched bamboo biochars. $J$ Analyt Applied Pyrolysis. 2018;131:101-12

23. Mehari ZH, Elad Y, Rav-David D, Graber ER, Meller HY. Induced systemic resistance in tomato (Solanum lycopersicum) against Botrytis cinerea by biochar amendment involves jasmonic acid signaling. Plant Soil. 2015;395:31-44.

24. Graber ER, Elad Y. Biochar impact on plant resistance to disease. In: Biochar and soil biota. Boca Raton: CRC Press; 2013. p. 41-68.

25. Frenkel O, Jaiswal AK, Elad Y, Lew B, Kammann C, Graber ER. The effect of biochar on plant diseases: what should we learn while designing biochar substrates? J Environ Engin Landsc Manage. 2017;25:105-13.

26. Rezaei N, Razzaghi F. Effect of different levels of water salinity and biochar on wheat yield under greenhouse conditions. Leuven: International Society for Horticultural Science; 2018.

27. Jones DL, Rousk J, Edwards-Jones G, DeLuca TH, Murphy DV. Biocharmediated changes in soil quality and plant growth in a three year field trial. Soil Biol Biochem. 2012;45:113-24.

28. Jin Z, Chen C, Chen X, Jiang F, Hopkins I, Zhang X, Han Z, Billy G, Benavides J. Soil acidity, available phosphorus content, and optimal biochar and nitrogen fertilizer application rates: a five-year field trial in upland red soil, China. Field Crops Res. 2019;232:77-87.

29. Wu Z, Zhang X, Dong Y, Xu X, Xiong Z. Microbial explanations for fieldaged biochar mitigating greenhouse gas emissions during a rice-growing season. Environ Sci Pollut Res. 2018;25:31307-17.

30. Jaiswal A, Frenkel O, Elad Y, Lew B, Graber E. Non-monotonic influence of biochar dose on bean seedling growth and susceptibility to Rhizoctonia solani: the "Shifted Rmax-Effect." Plant Soil. 2015;395:125-40.

31. Joseph S, Graber ER, Chia C, Munroe P, Donne S, Thomas T, Nielsen S, Marjo C, Rutlidge H, Pan GX, Li L, Taylor P, Rawal A, Hook J. Shifting paradigms: development of high-efficiency biochar fertilizers based on nanostructures and soluble components. Carbon Manage. 2013;4:323-43.

32. Qian L, Chen L, Joseph S, Pan G, Li L, Zheng J, Zhang X, Zheng J, Yu $X$, Wang J. Biochar compound fertilizer as an option to reach high productivity but low carbon intensity in rice agriculture of China. Carbon Manage. 2014;5:145-54.

33. Zheng J, Han J, Liu Z, Xia W, Zhang X, Li L, Liu X, Bian R, Cheng K, Zheng J, Pan G. Biochar compound fertilizer increases nitrogen productivity and economic benefits but decreases carbon emission of maize production. Agric Ecosyst Environ. 2017;241:70-8.

34. Schmidt H-P, Pandit B, Cornelissen G, Kammann C. Biochar-based fertilization with liquid nutrient enrichment: 21 field trials covering 13 crop species in Nepal: biochar based fertilization. Land Degradat Develop. 2017;28:2324

35. Taek-Keun OH, Shinogi Y, Chikushi J, Lee Y, Choi B. Effect of aqueous extract of biochar on germination and seedling growth of lettuce (Lactuca sativa L.). J Fac Agric Kyushu Univ. 2012;57:55-60.

36. Lou Y, Joseph S, Li L, Graber E, Liu X, Pan G-X. Water extract from straw biochar used for plant growth promotion: an initial test. BioResources. 2016;11:249-66.

37. Bian R, Li L, Shi W, Ma B, Joseph S, Li L, Liu X, Zheng J, Zhang X, Cheng K, Pan $G$. Pyrolysis of contaminated wheat straw to stabilize toxic metals in biochar but recycle the extract for agricultural use. Biomass Bioenergy. 2018:118:32-9

38. Bian R, Joseph S, Shi W, Li L, Taherymoosavi S, Pan G. Biochar DOM for plant promotion but not residual biochar for metal immobilization depended on pyrolysis temperature. Sci Total Environ. 2019;662:571-80.

39. Ippolito JA, Cui L, Kammann C, Wrage-Mönnig N, Estavillo JM, FuertesMendizabal T, Cayuela ML, Sigua G, Novak J, Spokas K, Borchard N. Feedstock choice, pyrolysis temperature and type influence biochar characteristics: a comprehensive meta-data analysis review. Biochar. 2020;2:421-38

40. Mukherjee A, Zimmerman AR, Harris W. Surface chemistry variations among a series of laboratory-produced biochars. Geoderma. 2011;163:247-55. 
41. Taherymoosavi S, Joseph S, Pace B, Munroe P. A comparison between the characteristics of single- and mixed-feedstock biochars generated from wheat straw and basalt. J Analyt Applied Pyrolysis. 2018;129:123-33.

42. SMEWW-3112, Metals by atomic absorption spectrophotometerSection 3110, in Standard Methods for the Examination of Water and Wastewater.

43. R. García and Báez AP, Atomic Absorption Spectrometry (AAS). 2012. $1-14$.

44. Taherymoosavi S, Joseph S, Munroe P. Characterization of organic compounds in a mixed feedstock biochar generated from Australian agricultural residues. J Analyt Applied Pyrolysis. 2016;120:441-9.

45. Sengupta D, Guha A, Reddy AR. Interdependence of plant water status with photosynthetic performance and root defense responses in Vigna radiata (L.) Wilczek under progressive drought stress and recovery. J Photochem Photobiol B. 2013;127:170-81.

46. Lichtenthaler HK. [34] Chlorophylls and carotenoids: Pigments of photosynthetic biomembranes. In: Methods in enzymology. Washington: Academic Press; 1987. p. 350-82.

47. Kumar A, Prasad MNV, Sytar O. Lead toxicity, defense strategies and associated indicative biomarkers in Talinum triangulare grown hydroponically. Chemosphere. 2012;89:1056-65.

48. Matejovic I, Durackova A. Comparison of microwave digestion, wet and dry mineralization, and solubilization of plant sample for determination of calcium, magnesium, potassium, phosphorus, sodium, iron, zinc, copper, and manganese. Commun Soil Sci Plant Anal. 1994;25:1277-88.

49. Archanjo BS, Mendoza ME, Albu M, Mitchell DRG, Hagemann N, Mayrhofer C, Mai TLA, Weng Z, Kappler A, Behrens S, Munroe P, Achete CA, Donne S, Araujo JR, van Zwieten L, Horvat J, Enders A, Joseph S. Nanoscale analyses of the surface structure and composition of biochars extracted from field trials or after co-composting using advanced analytical electron microscopy. Geoderma. 2017;294:70-9.

50. Joseph S, Husson O, Graber E, van Zwieten L, Taherymoosavi S, Thomas T, Nielsen S, Ye J, Pan G, Chia C, Munroe P, Allen J, Lin Y, Fan X, Donne S. The electrochemical properties of biochars and how they affect soil redox properties and processes. Agronomy. 2015;5:322.

51. Ruiz-Navarro A, Fernández V, Abadía J, Abadía A, Querejeta JI, Albaladejo J, Barberá GG. Foliar fertilization of two dominant species in a semiarid ecosystem improves their ecophysiological status and the use efficiency of a water pulse. Environ Exp Bot. 2019;167:103854.

52. Joseph S, Kammann Cl, Shepherd JG, Conte P, Schmidt H-P, Hagemann N, Rich AM, Marjo CE, Allen J, Munroe P, Mitchell DRG, Donne S, Spokas K, Graber ER. Microstructural and associated chemical changes during the composting of a high temperature biochar: Mechanisms for nitrate, phosphate and other nutrient retention and release. Sci Total Environ. 2018;618:1210-23.

53. Hagemann N, Joseph S, Schmidt H-P, Kammann Cl, Harter J, Borch T, Young RB, Varga K, Taherymoosavi S, Elliott KW, McKenna A, Albu M, Mayrhofer C, Obst M, Conte P, Dieguez-Alonso A, Orsetti S, Subdiaga E, Behrens S, Kappler A. Organic coating on biochar explains its nutrient retention and stimulation of soil fertility. Nat Commun. 2017;8:1089.

54. Miranda-Villagómez E, Trejo-Téllez LI, Gómez-Merino FC, Sandoval-Villa M, Sánchez-García P, Aguilar-Méndez MÁ. Nanophosphorus fertilizer stimulates growth and photosynthetic activity and improves $P$ status in rice. J Nanomater. 2019;2019:5368027.

55. Cai L, Cai L, Jia H, Liu C, Wang D, Sun X. Foliar exposure of $\mathrm{Fe}_{3} \mathrm{O}_{4}$ nanoparticles on Nicotiana benthamiana: evidence for nanoparticles uptake, plant growth promoter and defense response elicitor against plant virus. J Hazard Mater. 2020;393:122415.

56. Shang Y, Hasan MK, Ahammed GJ, Li M, Yin H, Zhou J. Applications of nanotechnology in plant growth and crop protection: a review. Molecules. 2019;24:2558.

57. Tian L, Shen J, Sun G, Wang B, Ji R, Zhao L. Foliar application of SiO2 nanoparticles alters soil metabolite profiles and microbial community composition in the pakchoi (Brassicachinensis L.) rhizosphere grown in contaminated mine soil. Environ Sci Technol. 2020;54(20):13137-46.

58. Pitambara A. Shukla YM, Nanofertilizers: A recent approach in crop production. In: Panpatte DG, Jhala YK, editors. Nanotechnology for agriculture: crop production \& protection. Singapore: Springer; 2019. p. 25-58.
59. Lateef A, Nazir R, Jamil N, Alam S, Shah R, Khan MN, Saleem M, Rehman S. Synthesis and characterization of environmental friendly corncob biochar based nano-composite - A potential slow release nano-fertilizer for sustainable agriculture. Environ Nanotech Monitor Manage. 2019:11:100212.

60. Ramírez-Rodríguez GB, Miguel-Rojas C, Montanha GS, Carmona FJ, Dal Sasso G, Sillero JC, Skov Pedersen J, Masciocchi N, Guagliardi A Pérez-de-Luque A, Delgado-López JM. Reducing nitrogen dosage in Triticum durum plants with urea-doped nanofertilizers. Nanomaterials. 2020;10:1043.

61. Davarpanah S, Tehranifar A, Davarynejad G, Abadía J, Khorasani R. Effects of foliar applications of zinc and boron nano-fertilizers on pomegranate (Punica granatum cv. Ardestani) fruit yield and quality. Scientia Horticult. 2016;210:57-64.

62. Meier S, Moore F, Morales A, González M-E, Seguel A, MeriñoGergichevich C, Rubilar O, Cumming J, Aponte H, Alarcón D, Mejías J. Synthesis of calcium borate nanoparticles and its use as a potential foliar fertilizer in lettuce (Lactuca sativa) and zucchini (Cucurbita pepo). Plant Physiol Biochem. 2020;151:673-80.

63. Abd El-Azeim MM, Sherif MA, Hussien MS, Tantawy IAA, Bashandy SO. Impacts of nano- and non-nanofertilizers on potato quality and productivity. Acta Ecol Sin. 2020;40(5):388-97.

64. Gomez A, Narayan M, Zhao L, Jia X, Bernal RA, Lopez-Moreno ML, Peralta-Videa JR. Effects of nano-enabled agricultural strategies on food quality: current knowledge and future research needs. J Hazard Mater. 2021;401:123385.

65. Graber ER, Tsechansky L, Lew B, Cohen E. Reducing capacity of water extracts of biochars and their solubilization of soil Mn and Fe. Eur J Soil Sci. 2014;65:162-72.

66. Safaei Z, Azizi M, Davarynejad G, Aroiee H. The effect of foliar application of humic acid and nanofertilizer (Pharmks ${ }^{\circledR}$ ) on yield and yield components of black cumin (Nigellasativa L.). J Medicin Plants By Products. 2014;3:133-40.

67. Rizwan M, Ali S, Ziaur Rehman M, Adrees M, Arshad M, Qayyum MF, Ali L, Hussain A, Chatha SAS, Imran M. Alleviation of cadmium accumulation in maize (Zeamays L.) by foliar spray of zinc oxide nanoparticles and biochar to contaminated soil. Environ Pollut. 2019;248:358-67.

68. Hu P, An J, Faulkner MM, Wu H, Li Z, Tian X, Giraldo JP. Nanoparticle charge and size control foliar delivery efficiency to plant cells and organelles. ACS Nano. 2020;14:7970-86.

69. de Freitas ST, Handa AK, Wu Q, Park S, Mitcham EJ. Role of pectin methylesterases in cellular calcium distribution and blossom-end rot development in tomato fruit. Plant J. 2012;71:824-35.

70. Saxena M, Maity S, Sarkar S. Carbon nanoparticles in 'biochar' boost wheat (Triticum aestivum) plant growth. RSC Advances. 2014;4:39948

71. Saha A, Basak BB, Gajbhiye NA, Kalariya KA, Manivel P. Sustainable fertilization through co-application of biochar and chemical fertilizers improves yield, quality of Andrographis paniculata and soil health. Indust Crops Products. 2019;140:111607.

72. Liu Y, Yue L, Wang Z, Xing B. Processes and mechanisms of photosynthesis augmented by engineered nanomaterials. J Environ Chem. 2019;16:430-45.

73. Rossi L, Fedenia LN, Sharifan H, Ma X, Lombardini L. Effects of foliar application of zinc sulfate and zinc nanoparticles in coffee (Coffeaarabica L.) plants. Plant Physiol Biochem. 2019;135:160-6.

74. Esteban R, Moran JF, Becerril JM, García-Plazaola JI. Versatility of carotenoids: an integrated view on diversity, evolution, functional roles and environmental interactions. Environ Exp Bot. 2015;119:63-75.

75. Cui B, Hu Z, Zhang Y, Hu J, Yin W, Feng Y, Xie Q, Chen G. Anthocyanins and flavonols are responsible for purple color of Lablabpurpureus (L.) sweet pods. Plant Physiol Biochem. 2016;103:183-90.

76. Kőrösi L, Bouderias S, Csepregi K, Bognár B, Teszlák P, Scarpellini A, Castelli A, Hideg É, Jakab G. Nanostructured TiO2-induced photocatalytic stress enhances the antioxidant capacity and phenolic content in the leaves of Vitis vinifera on a genotype-dependent manner. J Photochem Photobiol B: Biol. 2019;190:137-45.

77. Ghassemi-Golezani K, Farhangi-Abriz S. Biochar alleviates fluoride toxicity and oxidative stress in safflower (Carthamus tinctorius L.) seedlings. Chemosphere. 2019;223:406-15. 
78. Ammar A, BenAissa I, Mars M, Gouiaa M. Comparative physiological behavior of fig (Ficus carica L.) cultivars in response to water stress and recovery. Scientia Horticult. 2020;260:108881.

\section{Publisher's Note}

Springer Nature remains neutral with regard to jurisdictional claims in published maps and institutional affiliations.
Submit your manuscript to a SpringerOpen ${ }^{\odot}$ journal and benefit from:

- Convenient online submission

- Rigorous peer review

- Open access: articles freely available online

- High visibility within the field

- Retaining the copyright to your article

Submit your next manuscript at $\boldsymbol{\nabla}$ springeropen.com 